\title{
ELECTROENCEPHALOGRAPHIC MONITORING OF THE BRAIN FUNCTIONAL CONDITION IN MODERN UKRANIAN SCHOOLCHILDREN
}

\author{
Iryna V. Redka ${ }^{1,2}, 0$ ksana Ya. Mykhalchuk², Zhanna V. Sotnikova-Meleshkina ${ }^{2}$ \\ 'KHARKIV MEDICAL ACADEMY OF POSTGRADUATE EDUCATION, KHARKIV, UKRAINE \\ ${ }^{2}$ V.N. KARAZIN KHARKIV NATIONAL UNIVERSITY, KHARKIV, UKRAINE
}

\begin{abstract}
The aim: To monitor the brain functional state of generally healthy Ukrainian schoolchildren according to computer electroencephalography (EEG).

Materials and methods: EEG examination of 125 practically healthy (according to medical records) schoolchildren of both sexes, which were divided into 3 age groups: 1) 8-12 years old ( $n=49) ; 2$ ) 13-16 years old $(n=42) ; 3)$ 17-18 years old ( $n=34)$. EEG was recorded at rest with eyes closed and during functional tests (eye opening, hyperventilation). Visual and spectral analyzes of the EEG were carried out, types of EEG were determined according to A.E. Zhirmunskaya. (1991) in the adaptation of N.L. Gorbachevskaya et al. (1999). Results: The peak frequency of alpha activity is in the range of 9 to $11.5 \mathrm{~Hz}$, with a tendency to increase as you grow older. A disorganized type of EEG with a predominance of alpha activity dominates with an organized type of EEG. For most schoolchildren, normal EEG reactivity predominates in response to functional tests. The detection rate of short fragments of pathological activity in the background did not exceed $8 \%$, but increased to $20 \%$ with hyperventilation.

Conclusions: Only a third of modern Ukrainian schoolchildren classified as "healthy" have a physiological type of EEG, which indicates the optimal functional state of the brain. The remaining part of generally healthy schoolchildren have EEG changes, which reflect initial functional disorders mainly at the level of nonspecific structures and the brain stem.
\end{abstract}

KEY WORDS: EEG types, peak frequency, hyperventilation, schoolchildren

Wiad Lek. 2020;73(12 p. I):2634-2639

\section{INTRODUCTION}

According to the WHO, the incidence of neuropsychiatric diseases is continuously growing all over the world and these conditions are included in the group of so-called "diseases of civilization" by some authors. From this point of view, the progression of neuropsychiatric diseases in a population is regarded as the "price of adaptation" to rapidly changing spiritual, moral and socio-ecological living conditions, as well as to a significant increase in the information flow in which modern society operates [1].

According to a prospective study of the state of schoolchildren nervous system in dynamics of 1980-2008, increase in the neurogenic symptoms frequency was noted with prevailing headaches $(52.4 \%)$, cerebral asthenic syndrome (56.6\%), motor disinhibition (28.9\%), various obsessive movements (33.8\%) [2]. The close interconnection between the state of nervous system and somatic state of schoolchildren was determined [2;3]: since 1980, the level of pathological lesions by somatic pathology in the presence of functional disorders of the nervous system has been increased in 1.7 times, in the presence of chronic neurogenic diseases - in 1.9 times [2]. Research over the past decade also confirms a trend toward an increase in neuropsychiatric disorders among children [4-8]. It indicates the need for timely detection of functional disorders in the brain activity of schoolchildren in order to correct these conditions and prevent their transition to chronic pathology with addition of concomitant psychosomatic pathology.

Today, most of the researches is devoted to study of neurophysiological characteristics of schoolchildren with various pathologies [9-12], while the dynamics of the functional state of the schoolchildren's brain assigned to the group of practically healthy ones [13-16] remains on the sidelines .

\section{THE AIM}

The aim of the study was to monitor the functional state of the brain of generally healthy Ukrainian schoolchildren according to computer encephalography (cEEG).

\section{MATERIALS AND METHODS}

To achieve this goal, 125 generally healthy (according to medical records) schoolchildren of both sexes were randomly selected and divided into 3 age groups: 1$)$ childhood (8-12 years old, $\mathrm{n}=49) ; 2$ ) early adolescence $(13-16$ years, $\mathrm{n}=42)$; 3) late adolescence $(17-18$ years, $\mathrm{n}=34)$. The studies were carried out with the prior written consent of the parents and the verbal consent of the schoolchildren in compliance with the bioethical standards provided for by the Helsinki Declaration. 
Table I. The distribution of schoolchildren in accordance with the peak frequency of alpha band EEG

\begin{tabular}{|c|c|c|c|}
\hline $\begin{array}{c}\text { Peak frequency } \\
\text { of alpha band EEG }\end{array}$ & $\begin{array}{l}\text { Childhood } \\
\text { 8-12 years old } \\
(n=49)\end{array}$ & $\begin{array}{c}\text { Early adolescence } \\
\text { 13-16 years old } \\
(n=42)\end{array}$ & $\begin{array}{l}\text { Late adolescence } \\
\text { 17-18 years old } \\
(n=34)\end{array}$ \\
\hline Absent & $0.0 \%$ & $4.8 \%$ & $0.0 \%$ \\
\hline $8.0-8.5$ & $6.1 \%$ & $0.0 \%$ & $2.9 \%$ \\
\hline $8.5-9.0$ & $14.3 \%$ & $7.1 \%$ & $2.9 \%$ \\
\hline $9.0-9.5$ & $20.4 \%$ & $4.8 \%$ & $17.6 \%$ \\
\hline $9.5-10$ & $12.2 \%$ & $19.0 \%$ & $23.5 \%$ \\
\hline $10-10.5$ & $24.5 \%$ & $23.8 \%$ & $23.5 \%$ \\
\hline $10.5-11.0$ & $18.4 \%$ & $11.9 \%$ & $14.7 \%$ \\
\hline 11.0-11.5 & $4.1 \%$ & $11.9 \%$ & $11.8 \%$ \\
\hline $11.5-12.0$ & $0.0 \%$ & $16.7 \%$ & $2.9 \%$ \\
\hline
\end{tabular}

Table II. The distribution of schoolchildren by type of background EEG activity

\begin{tabular}{|c|c|c|c|}
\hline EEG Types & $\begin{array}{l}\text { Childhood } \\
\text { 8-12 years old } \\
(n=49)\end{array}$ & $\begin{array}{l}\text { Early adolescence } \\
\text { 13-16 years old } \\
(n=42)\end{array}$ & $\begin{array}{l}\text { Late adolescence } \\
\begin{array}{c}17-18 \text { years old } \\
(n=34)\end{array}\end{array}$ \\
\hline organized & $10.2 \%$ & $35.7 \%$ & $32.4 \%$ \\
\hline dyssynchronous & $20.4 \%$ & $11.9 \%$ & $23.5 \%$ \\
\hline $\begin{array}{l}\text { disorganized with a } \\
\text { predominance of alpha activity }\end{array}$ & $55.1 \%$ & $31.0 \%$ & $38.2 \%$ \\
\hline $\begin{array}{c}\text { disorganized without alpha } \\
\text { activity }\end{array}$ & $4.1 \%$ & $9.5 \%$ & $0.0 \%$ \\
\hline $\begin{array}{l}\text { hypersynchronous in alpha } \\
\text { activity }\end{array}$ & $10.2 \%$ & $7.1 \%$ & $2.9 \%$ \\
\hline hypersynchronous beta activity & $0.0 \%$ & $4.8 \%$ & $2.9 \%$ \\
\hline
\end{tabular}

EEG was monopolar recorded using an averaged reference electrode from 21 leads, located in accordance with the 10x20 system. The EEG study protocol included the following events: 1) a resting state with eyes closed (5 minutes); 2) resting state with open eyes (2.5 minutes); 3 ) hyperventilation (3 minutes).

A visual analysis of the EEG was performed with the identification of types according to the classification of A.E. Zhirmunskaya. (1991) in the adaptation of N.L. Gorbachevskaya et al. (1999) to childhood [1;3], as well as spectral analysis for standard frequency ranges: delta $(0.5-4 \mathrm{~Hz})$, theta $(4-8$ $\mathrm{Hz})$, alpha $(8-12 \mathrm{~Hz})$, beta-1 (12-20 Hz), beta-2 (20-30 Hz).

The study was carried out in accordance with the national norms of bioethics and statement of Helsinki declaration (1975, version of 2013) for medical research involving human subjects, including research on identifiable human material and data.

\section{RESULTS}

Qualitative and quantitative characteristics of alpha activity are key in assessing the functional state and degree of maturity of brain structures.

It was found that during the second childhood period the peak frequency of the alpha rhythm is $24.5 \%$ in the frequency range $9.5-10 \mathrm{~Hz}$, in $22.4 \%$ - in the frequency range $9-9.5 \mathrm{~Hz}$, in $20.4 \%$ in the range of $10-10.5 \mathrm{~Hz}$. In adolescence, in the overwhelming majority of schoolchildren, the peak frequency of the alpha rhythm is in the range of $11-11.5 \mathrm{~Hz}(45.2 \%$ and $35.3 \%$, respectively) and $10-10.5 \mathrm{~Hz}(28.6 \%$ and $23,5 \%$ respectively). It should be noted that under conditions of relative rest with closed eyes, $3.2 \%$ of schoolchildren of adolescence showed areas without frequency peak in alpha activity (Table 1).

The typical topographic distribution of the alpha activity of the background EEG is characteristic of $72.1 \%$ of schoolchildren, and the smoothing of zonal differences was found in $27.9 \%$.

In the vast majority of schoolchildren, the focus of maximum alpha activity was in the parietal (in $43.2 \%$ on the left and $44.0 \%$ on the right) and occipital (in $41.6 \%$ on the left and $46.4 \%$ on the right) areas. A focus shift of maximum alpha activity to the central regions was observed in $11.2 \%$ of schoolchildren in the left hemisphere and $7.2 \%$ of schoolchildren in the right hemisphere.

On the background EEG, 2.4\% observed areas of alpha activity depression lasting from 1 to 5 seconds against a background of medium-amplitude activity. At $1.6 \%$ of schoolchildren, outbreaks of high-amplitude alpha rhythm were observed mainly in the frontal leads. 
In the frontal and occipital leads, sites of beta activity were observed in $4.0 \%$ and $4.8 \%$ of schoolchildren, respectively.

Single discharges were sometimes recorded on the background EEG, which in clinical electroencephalography are considered as epi-phenomes such as acute waves (single $2.4 \%$, outbreaks $-8 \%$ ), acute + slow wave complex (3.2\%).

Short-term outbreaks of high-amplitude theta waves bilaterally-synchronously were detected on the background EEG in $8.0 \%$ of schoolchildren, and diffuse theta waves were detected in $15.2 \%$ of schoolchildren.

The following distribution of schoolchildren by the typology of background EEG was established: $42.4 \%$ disorganized type with a predominance of alpha activity, $24.8 \%$ - organized type, $20.0 \%$ - dyssynchronous type, $7.2 \%$ - hypersynchronous alpha rhythm type, $0.8 \%$ is a type of EEG hypersynchronous in beta rhythm, $4.8 \%$ is a disorganized type with a predominance of slow-wave activity. Age-related features of the distribution of EEG types are presented in table 2.

An analysis of the activation reaction, reflecting the maturity of the brain structures and the mobility of nervous processes, revealed the presence of an adequate reaction in the form of alpha rhythm depression in $96.0 \%$ of schoolchildren. At the same time, $1.6 \%$ of schoolchildren had no reaction to light activation, and $2.4 \%$ of schoolchildren experienced a paradoxical reaction in the form of an increase in the amplitude of the alpha rhythm.

A hyperventilation test, traditional in clinical neurophysiology, was used as a load test. It was found that $81.6 \%$ of schoolchildren had an adequate reaction of rhythm synchronization in response to hyperventilation, $4.8 \%$ had excessive rhythm synchronization, $4.0 \%$ had no reaction, and $8.8 \%$ of schoolchildren experienced a disorder of the form a significant increase in the number and duration of flashes of slow wave activity or the dominance of slow wave activity.

Compared with the background activity, some schoolchildren observed: increased beta-rhythmic activity in the frontal (10.4\%) and occipital (15.2\%) leads; an increase in the number of theta waves is diffuse (24.0\%); an increase in the frequency of flashes of high-amplitude theta (19.2\%) and delta (11.2\%) waves bilaterally-synchronously; an increase in the frequency of alpha rhythm depression $(4.0 \%)$ and a slowed alpha rhythm alternating with theta activity (6.4\%) An increase in epileptiform activity was also observed: acute alpha waves (single $-8.0 \%$, outbreaks $-8 \%$ ), peak wave activity (4.0\%), and acute + slow wave complexes (2.4\%).

\section{DISCUSSION}

The trajectory of the brain development is largely genetically determined, but at the same time, environmental factors can influence this process. For example, children brought up in boarding schools are characterized by a higher power of slow-wave EEG activity [17-20]. A similar pattern was observed in children living in families with a low socio-eco- nomic status, which are characterized by poor nutrition or unsanitary living conditions [21;22]. The effects of learning [23] and motor activity [24] on the nature of the EEG pattern are also known. Thus, morphological and functional changes in the student's body and socio-economic factors create the prerequisites for the formation of central nervous system dysfunction $[1,22]$, which prompted us to conduct EEG monitoring in healthy pupils.

It is known that from preschool to adolescence, the human brain changes significantly due to trimming of unused synapses and myelination of long axons [25], which is reflected in the characteristic features of the electroencephalogram at rest, consisting in decreasing the power of the delta and theta ranges from increase in age [14-16; 26-29]. It is reflected in our data on an increase in the peak frequency of alpha activity in healthy schoolchildren as they grow older.

Summarizing the results of EEG monitoring, it can be stated that only $27 \%$ of Ukrainian schoolchildren are characterized by optimal functional state of the brain, while the remaining part of schoolchildren have an average of 1-1.3 disturbances in the activity of cerebral structures, mainly of a functional nature. Among them, changes to the functional activity of median nonspecific structures (35\%), brain stem (23\%), diencephalic structures (13\%), and also diffuse changes in the whole brain (15\%) come to the fore. Changes in the cortical/subcortical balance (8\%) and changes in the activity of limbic structures (7\%) are much less common.

It should be noted that according to our results the frequency of functional disorders at the level of diencephalic structures increases significantly, starting from early adolescence, reaching a twofold increase in schoolgirls. This is consistent with literature data on the increased activity of diencephalic brain structures in early adolescence due to activation of higher autonomic centers and hormonal imbalance [13; 27].

According to [2], diffuse changes of a cerebral nature in schoolchildren may become a risk factor in the development of prenosological forms of neurovegetative disorders (e.g., vegetative lability) with subsequent manifestation in neurocirculatory dystonia.

In $2 \%$ of the examined schoolchildren (the period of the second childhood), a focus of epi-activity was detected, however, according to a survey of parents and schoolchildren, the corresponding clinical symptoms were not observed. It should be noted that our data are consistent with data [30-32], in which the frequency of detection of typical epileptiform discharges on healthy children by EEG ranges from 1.2 to 5.0\%. Most likely, epileptiform discharges in the absence of a connection with clinical manifestations or hereditary burden of epilepsy should be considered as a feature of the individual development of the central nervous system.

$7 \%$ of schoolchildren showed paroxysmal brain activity, and $1 \%$ of schoolchildren had a paroxysmal state of the brain, which prevailed during the second childhood. This may be due to the lower maturity of cortical-subcortical 
interactions during the second childhood, which contributes to an increased reactivity of cerebral structures to disturbing influences.

To date, there is no single generally accepted classification of EEG types. In foreign literature, a typology of EEG phenomena proposed in [33] is widely used: slow diffuse activity with or without low-frequency alpha activity; focal non-epileptic anomalies (slow-wave activity or decreased activity); a mixed increase in slow-wave and high-frequency activity; disturbances in the activity of the frontal lobes in the form of excessive theta or alpha activity; violation of frontal asymmetry; high-frequency alpha activity in the caudal areas; excessive spindle-shaped beta activity mainly in the rostral regions; total low-amplitude EEG; epileptiform activity (peak wave, sharp waves, paroxysmal EEG). However, in our opinion, this approach describes only individual EEG patterns that can occur in various functional states. A more holistic approach is that proposed in $[26 ; 34 ; 35]$, since it considers the presence of not only individual EEG phenomena, but also zonal differences, the nature of organization, and the frequency-amplitude characteristics of the EEG: high-frequency alpha activity in the caudal areas; excessive spindle-shaped beta activity mainly in the rostral regions; total low-amplitude EEG; epileptiform activity (peak wave, sharp waves, paroxysmal EEG).

According to data [26], in healthy children (7-9 years old), organized (72\%), disorganized with a predominance of alpha activity (15\%) and asynchronous (13\%) types of EEG are found. Our data are somewhat at variance with the above, since the disorganized type of EEG with a predominance of alpha activity (42.4\%), organized (24.8\%) and asynchronous (18.4\%) types of EEG prevailed in the contingent studied by us. Perhaps this is due to differences in the age composition of schoolchildren, which was significantly wider in our study (8-18 years). According to a longitudinal study [26], the typology of EEG is preserved throughout school age, with the exception of puberty, when a disorganized EEG with a predominance of alpha activity becomes an organized type of EEG.

Various types of EEG (with the exception of organized) are due to a shift in the balance between the synchronizing and desynchronizing brain structures. So, in [35] it is indicated that the asynchronous type of EEG is associated with inhibition of the activity of nonspecific thalamic nuclei and increased activity of the reticular formation of the brain stem and posterior hypothalamus. A type of EEG hypersynchronous in alpha activity is formed under conditions of inhibition of the activity of the brain stem reticular formation and posterior hypothalamus against the background of increased activity of nonspecific thalamic nuclei.

According to the data of [36], the asynchronous and hypersynchronous EEG variants can be a consequence of perinatal pathology. In both cases, the dominant complaints are emotional instability, anxiety, agitation, restlessness, sleep disturbance, increased fatigue, and school difficulties.

Despite the fact that the asynchronous type of EEG has the highest genetic determinism, at the same time, there is a connection between this type of EEG and a violation of the blood supply to the vertebra-basilar basin [36].

The disorganized type with a predominance of slowwave activity is presumably due to the state of irritation of the non-specific and associative thalamic nuclei against the background of inhibition of the activity of the reticular formation and posterior hypothalamus [35]. A disorganized type of EEG with a predominance of slowwave activity indicates the inferiority of the subcortical systems providing the optimal tone of the cerebral cortex. At the same time, complaints appear testifying to emotional lability, mental exhaustion and impaired attention function [36].

\section{CONCLUSIONS}

Despite the nosologically non-specificity of electroencephalographic studies, they make it possible to identify the category of schoolchildren who should be assigned to the group of neurological risk. According to our data, only a third of modern Ukrainian schoolchildren classified as "healthy" have a physiological type of EEG, indicating an optimal functional state brain. In most schoolchildren, EEG changes reflect initial functional disorders, localized mainly at the level of nonspecific structures and the brain stem. Since early adolescence, schoolgirls double the frequency of functional disorders at the level of diencephalic structures.

Such changes in the functional state of the brain, not accompanied by clinical manifestations, when combined with other risk factors create the prerequisites for the formation of neuropsychiatric pathology in the absence of adequate health-improving measures.

\section{REFERENCES}

1. Troshin V.D. Dostizheniya neyronauk i strategii preventologii. Meditsinskiy almanakh. 2013; 1(25):101-104. (in Russian).

2. Kamaev I.A., Chekalova S.A. Strategiya profilaktiki nevrologicheskoy zabolevaemosti detey shkolnogo vozrasta [Strategy for preventing neurological diseases in school-age children]. Rossiyskiy pediatricheskiy zhurnal. 2012; 3: 54-59. (in Russian).

3. Zhdanova L.A., Salova M.N., Runova O.S., Klepikova T.A. Vozrastnye osobennosti formirovaniya neyrosomaticheskoy patologii u detey i podkhody k okazaniyu reabilitatsionnoy pomoshchi [Age related features of the formation of neurosomatic pathology in children and approaches to providing rehabilitation assistance]. Lechenie $\mathrm{i}$ profilaktika. 2020; 1(10): 5-10. (in Russian).

4. Kuchma V.R., Sukhareva L.M., Rapoport I.K., Shubochkina E.I. et al. Populyatsionnoe zdorove detskogo naseleniya, riski zdorovyu i sanitarno-epidemiologicheskoe blagopoluchie obuchayushchikhsya: problemy, puti resheniya, tekhnologii deyatelnosti [Population health of children, risks to health and sanitary and epidemiological wellbeing of students: problems, ways of solution and technology of the activity]. Gigiena i sanitariya. 2017; 96(10): 990-995. (in Russian).

5. Rapoport I.K., Tsameryan A.P. Osobennosti formirovaniya nervnopsikhicheskikh rasstroystv i narusheniy zreniya u moskovskikh uchashchikhsya v protsesse obucheniya v shkole. Zdorove naseleniya i sreda obitaniya. 2019; 5 (314): 20-27. (in Russian). 
6. Egorova, V.B., Savvina N.V., Munkhalova Y.A., Dmitrieva T.G. et al. Health state of adolescents in the Republic Sakha (Yakutia). Wiadomosci lekarskie. 2016; 69 (1 Pt 2): 64-68.

7. Fedorchenko R.A., Mykhaylenko V.L., Taranov V.V., Badiuk N.S. Diseases of the nervous system among schoolchildren and youth in modern training conditions. Journal of Education, Health and Sport. 2017; 7(3): 606-613. doi: http://dx.doi.org/10.5281/zenod0.570931.

8. Sukhonosova 0 . Comparison of prevalence, incidence and disability from nervous diseases and epilepsy among children of the Kharkiv region and Ukraine. Mezhdunarodnyy nevrologicheskiy zhurnal. 2017; 1 (87):80-84.

9. Helgadóttir H., Gudmundsson 0́.0́., Baldursson G. et al. Electroencephalography as a clinical tool for diagnosing and monitoring attention deficit hyperactivity disorder: a cross-sectional study. BMJ Open. 2015. 5(1): e005500. doi: 10.1136/bmjopen-2014-005500.

10. Jäncke L., Saka M.Y., Badawood 0., Alhamadi N. Resting-state electroencephalogram in learning-disabled children: power and connectivity analyses. Neuroreport. 2019; 30(2): 95-101. doi: 10.1097/ WNR.0000000000001166.

11. Lau-Zhu A., Fritz A., McLoughlin G. Overlaps and distinctions between attention deficit/hyperactivity disorder and autism spectrum disorder in young adulthood: Systematic review and guiding framework for EEGimaging research. Neurosci Biobehav. 2019; 96:93-115. doi: 10.1016/j. neubiorev.2018.10.009.

12. Newson J.J., Thiagarajan T.C. EEG Frequency Bands in Psychiatric Disorders: A Review of Resting State Studies. Frontiers in human neuroscience. 2019; 12: 24. doi: 10.3389/fnhum.2018.00521.

13. Komkova Yu.N. Elektricheskaya aktivnost golovnogo mozga u detey i podrostkov na raznykh stadiyakh polovogo sozrevaniya v sostoyanii pokoya [Brain electric activity in children and adolescents at rest at the different stages of sexual maturation]. Novye issledovaniya. 2018; 1 (54): 4-25. (in Russian).

14. Alahmadi N., Evdokimov S.A., Kropotov Y.J., Müller A.M. et al. Different Resting State EEG Features in Children from Switzerland and Saudi Arabia. Frontiers in human neuroscience. 2016; 10: 12. https://doi. org/10.3389/fnhum.2016.00559.

15. Hunt B.A.E., Wong S.M., Vandewouw M.M., Brookes M.J. et al. Spatial and spectral trajectories in typical neurodevelopment from childhood to middle age. Netw Neurosci. 2019; 3(2): 497-520. doi:10.1162/ netn_a_00077.

16. Kaminska A., Eisermann M., Plouin P. Child EEG (and maturation). Handbook of clinical neurology. 2019; 160: 125-142. doi:10.1016/ B978-0-444-64032-1.00008-4.

17. Kulenkova A.A., Dyagileva Yu.0., Pavlenko V.B., Belalov V.V. et al. Bioelektricheskaya aktivnost mozga v rannem detstve, spetsifichnaya dlya detey, prozhivayushchikh v detskikh domakh. Zhurnal vysshey nervnoy deyatelnosti imeni I.P. Pavlova. 2015; 65 (5): 607-615. (in Russian).

18. Bick J., Zajac L., Simons R., Dozier M. Early Parenting Intervention and Adverse Family Environments Affect Neural Function in Middle Childhood. Biological psychiatry. 2019; 85(4): 326-335. https://doi. org/10.1016/j.biopsych.2018.09.020.

19. Debnath R., Tang A., Zeanah C.H., Nelson C.A. et al. The long-term effects of institutional rearing, foster care intervention and disruptions in care on brain electrical activity in adolescence. Developmental Science. 2020; 23 (1): 9. doi:10.1111/desc.12872.

20. Marshall P.J., Fox N.A. A comparison of the electroencephalogram between institutionalized and community children in Romania. Bucharest Early Intervention Project Core Group. J Cogn Neurosci. 2004; 16 (8): 1327-1338. doi: 10.1162/0898929042304723.
21. Kustubaeva A.M. EEG maturation in children in different social groups. Anxiety level and EEG indexes. Exp. Psychol. 2013; 5: 5-20.

22. Maguire M.J., Schneider J.M. Socioeconomic status related differences in resting state EEG activity correspond to differences in vocabulary and working memory in grade school. Brain Cognition. 2019; 137: 8. doi:10.1016/j.bandc.2019.103619.

23. Gupta R.K., Rajeswaran J., Bhattacharya A., 0jha A. et al. Academic Stress in School Children: Behavioural and Electrophysiological Outcomes Study. Indian Journal of Clinical Psychology. 2018; 45 (2): 18-22.

24. Kamijo K., McGowan A.L., Pontifex M.B. Effects of physical activity on cognition in children and adolescents. American Psychological Association handbooks in psychology series. APA handbook of sport and exercise psychology.2019; 2. Exercise psychology:331-343. https:// doi.org/10.1037/0000124-017.

25. Gómez, C.M., Rodríguez-Martínez, E.I., Fernández, A., Maestú, F. et al. Absolute Power Spectral Density Changes in the Magnetoencephalographic Activity During the Transition from Childhood to Adulthood. Brain topography. 2017; 30 (1): 87-97. https:// doi.org/10.1007/s10548-016-0532-0.

26. Gorbachevskaya N.L., Yakupova L.P. Osobennosti kartiny EEG u bolnykh s razlichnyimi tipami autisticheskikh rasstroystv. Autizm v detstve. Moskva: Medistina. 1999: 131-170. (in Russian).

27. Farber D.A., Alferova V.V. Elektroentsefallogramma detey i podrostkov. Moskva: Pedagogika. 1972: 216. (in Russian).

28. Gasser T., Verleger R., Bächer P., Sroka L. Development of the EEG of school-age children and adolescents. I. Analysis of band power. Electroencephalogr Clin Neurophysiol. 1988; 69 (2): 91-99. doi: 10.1016/0013-4694(88)90204-0.

29. Perone S., Palanisamy J., Carlson S.M. Age-related change in brain rhythms from early to middle childhood: Links to executive function. Development Science. 2018; 21 (6), article e12691. doi:10.1111/ desc.12691.

30. Glukhova L.Yu. Klinicheskoe znachenie epileptiformnoy aktivnosti na elektroentsefalogramme [Clinical significance of epileptiform activity in electroencephalogram]. Russkiy zhurnal detskoy nevrologii. 2016; 4: 8-19. (in Russian).

31. Darwish A.H., Alshahawy A.K., El-Shehaby W.A. Epileptiform Activity in Electroencephalogram of Normal Children. Neuropediatrics. 2017; 48(5): 356-362. doi:10.1055/s-0037-1603514.

32. Eeg-Olofsson 0., Petersen I., Selden U. The development of the electroencephalogram in normal children from the age of 1 through 15 years. Paroxysmal activit. Neuropaediatrie. 1971; 2: 375-404. doi: 10.1055/s-0028-1091791.

33. Johnstone J., Gunkelman J., Lunt J. Clinical Database Development: Characterization of EEG Phenotypes. Clinical EEG and neuroscience. 2005; 36 (2): 99-107. doi: 10.1177/155005940503600209.

34. Gorbachevskaya N.L. Osobennosti formirovaniya EEG u detey v norme i pri raznykh tipakh obshchikh (pervazivnykh) rasstroystv razvitiya [avtoreferat dysertatsiyi]. M.: MGU. 2000. (in Russian).

35. Zhirmunskaya E.A. V poiskakh obyasneniya fenomenov EEG. Moskva: NFP Biola. 1996: 117. (in Russian).

36. Kozhushko N.Yu.Vozrastnye osobennosti formirovaniya bioelektricheskoy aktivnosti mozga u detey sotdalennymi posledstviyami perinatalnogo porazheniya TsNS. Soobshchenie II. Spontannaya aktivnost [Developmental Features of the Brain Bioelectrical Activity in Children with Remote Consequences of a Perinatal Lesion of the CNS. II. EEG Typology in Normal and Mental Disorders]. Fiziologiya cheloveka. 2005; 31 (1): 5-14. (in Russian). 


\section{ORCID and contributionship:}

Iryna V. Redka: 0000-0002-9620-9452 A, B, D, E, F

Oksana Ya. Mykhalchuk: 0000-0001-9628-4754 B,D,F

Zhanna V. Sotnikova-Meleshkina: 0000-0001-5534-8264 ${ }^{C, D, F}$

\section{Conflict of interest:}

The Authors declare no conflict of interest.

\section{CORRESPONDING AUTHOR}

Zhanna V. Sotnikova-Meleshkina

V.N. Karazin Kharkiv National University

6 Svobody Sq., 61022 Kharkiv, Ukraine

tel: +380507094393

e-mail:zhanna.v.sotnikova@karazin.ua

Received: 15.12 .2019

Accepted: 08.09.2020

A - Work concept and design, B - Data collection and analysis, C - Responsibility for statistical analysis,

D-Writing the article, $\mathbf{E}$-Critical review, $\mathbf{F}$ - Final approval of the article 